\title{
The Current Status of Green Space around Elementary Schools: A Case Study of Malang, Indonesia
}

\author{
Sri Een Hartatik ${ }^{1}$ and Akemi Itaya ${ }^{1, *}$
}

\begin{abstract}
Green space is important for childhood development, particularly in developing countries. The city of Malang, Indonesia has experienced steady economic and population growth in recent years, but green space area in the urban environment has been declining. In this study, we elucidated the status of green space accessible to children in Malang, and discussed ways of improving green space use. We identified green spaces around 291 elementary schools using satellite remote sensing. A RapidEye satellite image, which covered the study area with a 5-m ground sample distance, was acquired on May 20, 2015. From this image, the area of green spaces within $1 \mathrm{~km}$ radius circles of elementary schools were calculated. The total area of green space in the city was $45.439 \mathrm{~km}^{2}, 41.3 \%$ of the total city area. Smaller green spaces were located near the city center, whereas larger green spaces were located in the southeastern part of the city. The green space ratio within $1 \mathrm{~km}$ of 96 schools was less than $15 \%$, and it was $15-30 \%$ around 104 schools. Overall, there were few green spaces within walking distance of schools in Malang. The green space ratio in the city center was also low. Green spaces in the city should be maintained, and additional opportunities should be provided for children to access green spaces.
\end{abstract}

Keywords: accessibility, childhood, green space, landscape, urbanization

\section{INTRODUCTION}

Urban green space provides residents with important environmental services such as water resource management, biodiversity conservation, carbon sequestration, and landscape aesthetics (Arifin and Nakagoshi, 2011; Byomkesh et al., 2012; Coombes et al., 2010; Maas et al., 2006). Urban green space includes public parks, nature conservation areas, sports fields, riparian areas (e.g., stream and river banks), greenways and nature trails, community gardens, roadside trees, green walls, green alleyways, and cemeteries (Roy et al., 2012). Private backyards, communal grounds of apartment buildings, and corporate campuses are also considered private green spaces (Wolch et al., 2014). Green space is important for children living in urban areas (Ioja et al., 2014; Mizuki and Minami, 2003; Richardson et al., 2017), as adult environmental opinions are formed by experiences with nature during childhood (Ewert et al., 2005; Jim and Shan, 2013). Nature-focused kindergartens and schools have provided children with opportunities for inter-

\footnotetext{
* Corresponding author. E-mail: itaya@bio.mie-u.ac.jp

${ }^{1}$ Graduated School of Bioresources, Mie University, 1577 Kurimamachiya-cho, Tsu-shi, Mie, 514-8507 Japan
}

acting with green spaces in Europe and the United States (Elliott and Chancellor, 2014; Fjørtoft and Sageie, 2000; MacEachren, 2013; Schäffer and Kistemann, 2012). Children can explore nature in green spaces in a supervised or unsupervised manner (Jansson et al., 2016). Green spaces not only provide children with opportunities to experience nature (Coolen and Meesters, 2012), but are also places for children to make friends (Seeland et al., 2009). Because of these benefits, Glackin and Jones (2012) suggested that local green spaces should be used for teaching and studying science in south London, United Kingdom. Kweon et al. (2017) and Wu et al. (2014) also showed that children who study in school environments with more trees perform better academically. However, rapid urbanization and population growth have led to changes in land use and cover, resulting in an overall reduction in green space area (Dewan and Yamaguchi, 2009; Kusimi, 2008; Ramdani et al., 2015).

As urbanization and populations increase in developing countries (Dewan and Yamaguchi, 2009; Kusimi, 2008; Ramdani et al., 2015), it is important to understand the status of green space around children in these countries to improve green space access. In 2015, 53.7\% of the population in Indonesia lived in urban areas (World Bank, 2016). The urban population is projected to exceed the rural population by 2020 . In $2050,70 \%$ of Indonesians are projected to live in urban areas, a higher pro- 


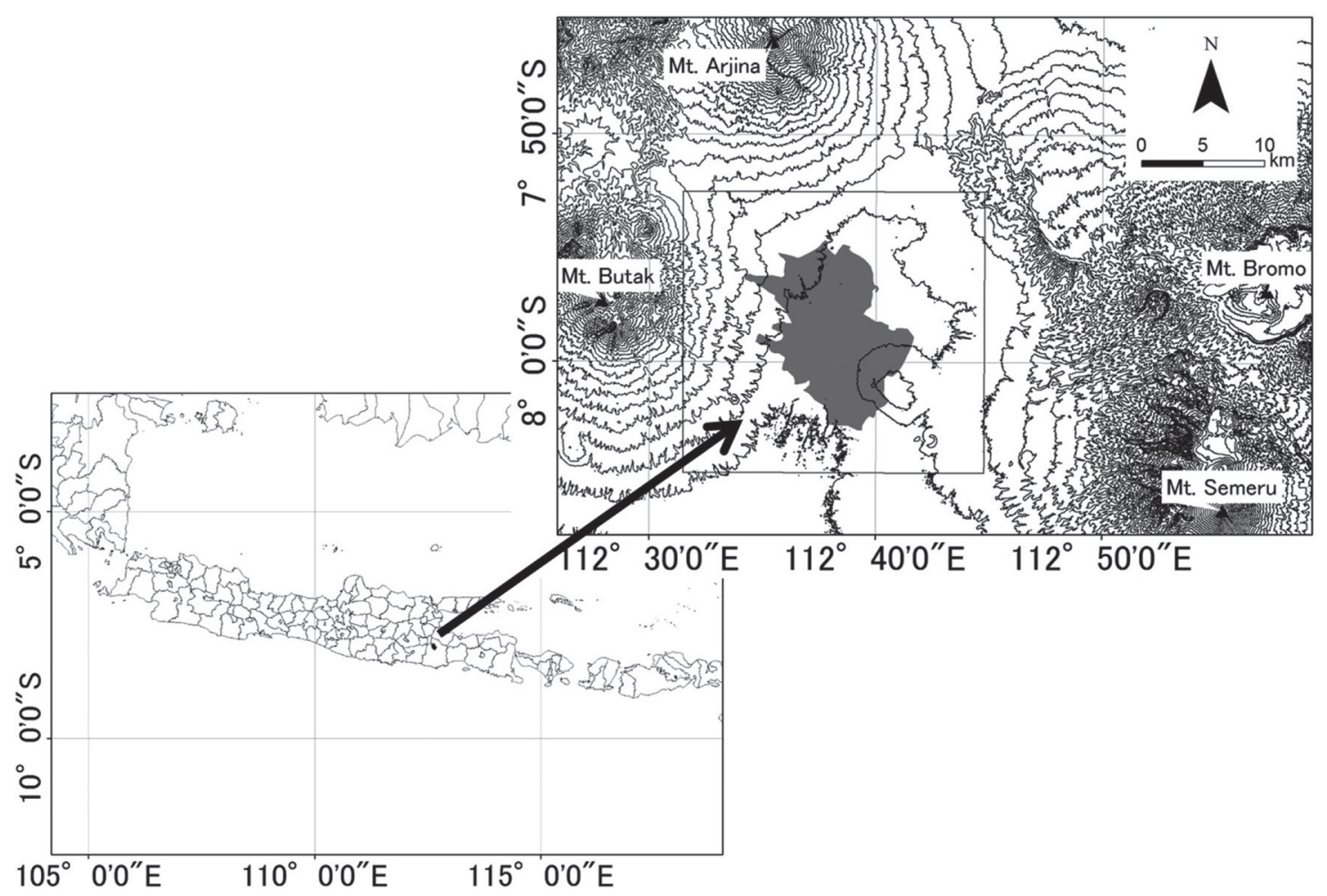

Fig. 1 Location of Malang, Indonesia (gray area). The delineated area is that covered by the satellite image. The 100-m interval contour lines were generated using a digital surface model (DSM) and data obtained from the Advanced Land Observing Satellite (ALOS). The city is surrounded by mountains and mountain ranges.

portion than in other Asian countries (United Nations, 2014). As cities become more urbanized, a smaller proportion of the urban population will experience nature directly (Cox et al., 2017). Thus, children in urban areas in Indonesia may have less access to green space. However, little is known about the status of green space around children in Indonesia. Although studies have been conducted on broad-scale land-cover changes and land management in urban areas (Achmad et al., 2015; Agaton et al., 2016; Ramdani et al., 2015; Wolfersberger et al., 2015), these studies did not focus on green space around children. Malang, the second largest city in East Java, is a typical example of a rapidly urbanizing city in Indonesia. Urbanization in Malang is occurring in an uncontrolled manner (Ramdani et al., 2015), with increasing housing development and a decreasing area of agricultural land and forests. Urban area cover increased from $21 \%$ in 2001 to $40 \%$ in 2014 (Ramdani et al., 2015). This rapid urbanization has resulted in a steady decrease in green space in Malang.

Although the optimal green space area for children is not known, Indonesia has developed several green space indices for city planning. According to government regulations, at least $30 \%$ of the city area should be designated as green space, and at least $20 \%$ of this green space should be publicly accessible (Ministry of Public Works, 2008). Additionally, the World Health Organization (WHO) recommends that each city inhabitant should have access to at least $9 \mathrm{~m}^{2}$ of green space (OECD, 2013). In Japan, the Nishinomiya city government mandated that each residential area should have a green space ratio, defined as the proportion of vegetation to visible land area, of at least $15 \%$ (Susaki and Kubota, 2017).

In this study, we used satellite remote-sensing to elucidate the current status of green space around children in elementary schools in Malang, Indonesia, and discuss ways to improve access to green space.

\section{MATERIALS AND METHODS}

\section{Study Site}

Our study site was Malang, the second largest city in East Java, Indonesia (Fig. 1). Malang has an area of $110.06 \mathrm{~km}^{2}$, and is surrounded by mountains and mountain ranges, including Mt. Bromo, Mt. Butak, Mt. Arjuna, and Mt. Semeru. Malang comprises a large southern plateau, northern fertile highlands, an eastern plateau with less fertile soil, and a vast western plateau (Pemerintah Kota Malang, 2018). The downtown area is located at the center of the city. According to the 2010 census, the population of Malang is 820,243 , and widely dispersed throughout the city. The population has doubled over the last 40 years, and is estimated to reach 874,890 in 2020 (Badan Pusat Statistik, 2015). The economy in Malang has been growing steadily, and the local government has been unable to control the urbanization process and related population growth and urbanization (Ramdani et al., 2015). In 2003, the city was composed of $54.48 \%$ 


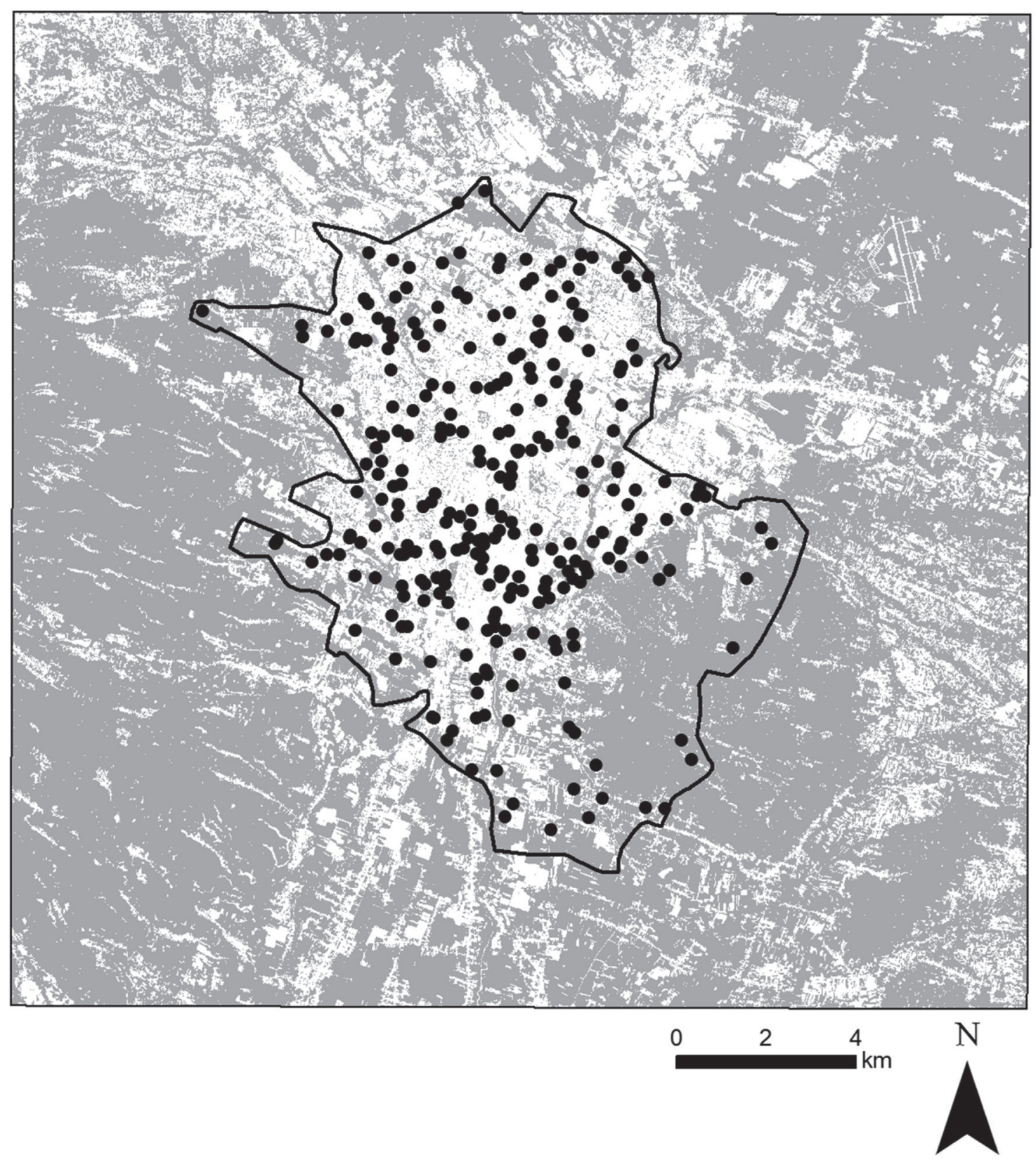

Fig. 2 Green spaces detected using the maximum-likelihood method to classify the RapidEye satellite image (gray area). Points represent the locations of elementary schools.

vegetation, $7.25 \%$ open land, and $38.27 \%$ constricted land (Purwanto et al., 2016). Ten years later, the composition changed to $35.54 \%$ vegetation, $2.41 \%$ open land, and $62.05 \%$ constricted land (Purwanto et al., 2016). During this period, west and southeast Malang started to develop as well.

\section{Location of Elementary Schools}

We obtained the names and addresses of 330 elementary schools in Malang (Malang District Board of Education, 2018). Based on these addresses, we conducted a visual assessment of each location using satellite images hosted by Google Earth Pro and Google Street View, and the latitude and longitude of each elementary school was recorded. The locations of 291 Malang schools were conclusively identified (Fig. 2). The locations of 39 schools could not be determined conclusively.

Detection of Green Spaces around Elementary Schools Using Remote-sensing

Green spaces were detected using a RapidEye satellite image, which was acquired on May 20, 2015, and covered the study area at a spatial resolution of $5 \mathrm{~m}$ (Fig. 1). After normalized difference vegetation index (NDVI) values were calculated using red $(630-680 \mathrm{~nm})$ and near infrared $(760-850 \mathrm{~nm})$ bands, the NDVI layer were combined with red, green $(520-590 \mathrm{~nm})$ and blue (440-510 nm) bands. The supervised classification, which was maximum likelihood classifier, was applied for a combined 
Table 1 Accuracy of classification of land cover types on the RapidEye satellite image acquired on May 20, 2015

\begin{tabular}{|c|c|c|c|c|c|c|c|}
\hline & & \multicolumn{6}{|c|}{ Interpretation on Google Earth } \\
\hline & & $\begin{array}{c}\text { Woody } \\
\text { vegetation }\end{array}$ & $\begin{array}{c}\text { Non-woody } \\
\text { vegetation }\end{array}$ & Built-up & Bare land & Total & $\begin{array}{c}\text { User's accuracy } \\
(\%)\end{array}$ \\
\hline \multirow{6}{*}{$\begin{array}{c}\text { Testing } \\
\text { data }\end{array}$} & Woody vegetation & 39 & 8 & 0 & 3 & 50 & 78.0 \\
\hline & Non-woody vegetation & 5 & 41 & 1 & 3 & 50 & 82.0 \\
\hline & Built-up & 2 & 2 & 44 & 2 & 50 & 88.0 \\
\hline & Bare land & 0 & 10 & 7 & 33 & 50 & 66.0 \\
\hline & Total & 46 & 61 & 52 & 41 & 200 & \\
\hline & Producer's accuracy (\%) & 84.8 & 67.2 & 84.6 & 80.5 & & \\
\hline
\end{tabular}

Overall accuracy $=78.5 \%$, Kappa $=0.71$

image. Land cover was grouped into four categories: Woody vegetation, Non-woody vegetation, Built-up and Bare land. In our dataset, 40 polygons were used for classification training, and 200 points were used to assess classification accuracy. Training and testing data were manually annotated by visually interpreting photographs obtained from Google Earth Pro and Google Street View. A confusion matrix was constructed by comparing test data with predicted values to quantify overall accuracy and the kappa coefficient (Congalton, 1991; Forestry and Forest Products Research Institute, 2012; Story and Congalton, 1983). We defined woody vegetation and non-woody vegetation as green spaces. Image processing and pre-processing, such as converting digital numbers to top-of-atmosphere reflectance, were carried out using ERDAS IMAGINE 2016 (Hexagon Geospatial).

We generated a circle with a radius of $1 \mathrm{~km}$ from the center of each school, and the green space area within these circles was calculated using ArcGIS 10.0 (ESRI). The reported walking rate of children is $4.3 \mathrm{~km} / \mathrm{hr}$ (McDonald, 2008); thus, distances of 1 $\mathrm{km}$ can be covered by children within approximately 15 minutes.

\section{RESULTS AND DISCUSSION}

\section{Detection of Green Spaces Using a Satellite Image}

The overall accuracy was $78.5 \%$, and the kappa coefficient was 0.71 (Table 1). The accuracy of detecting green spaces improved to $86.3 \%$ when woody vegetation and non-woody vegetation were combined as green space in urban areas. The green space detected on our map is displayed in Fig. 2.

Smaller green spaces were located in the city center, whereas larger green spaces were located in the southeastern part of the city. Total green space area in Malang was $45.43 \mathrm{~km}^{2}$ and the overall green space ratio was $41.3 \%$. The per capita green space area was $55.38 \mathrm{~m}^{2}$. The green space area in Malang is larger than the area guidelines proposed by WHO and the city of Nishinomiya (Susaki and Kubota, 2017). In contrast, the capital of Indonesia, Jakarta, which is also the largest city in Indonesia, has $7.08 \mathrm{~m}^{2}$ of green space per inhabitant (Kirmanto et al., 2012) and far fewer green spaces than Malang.

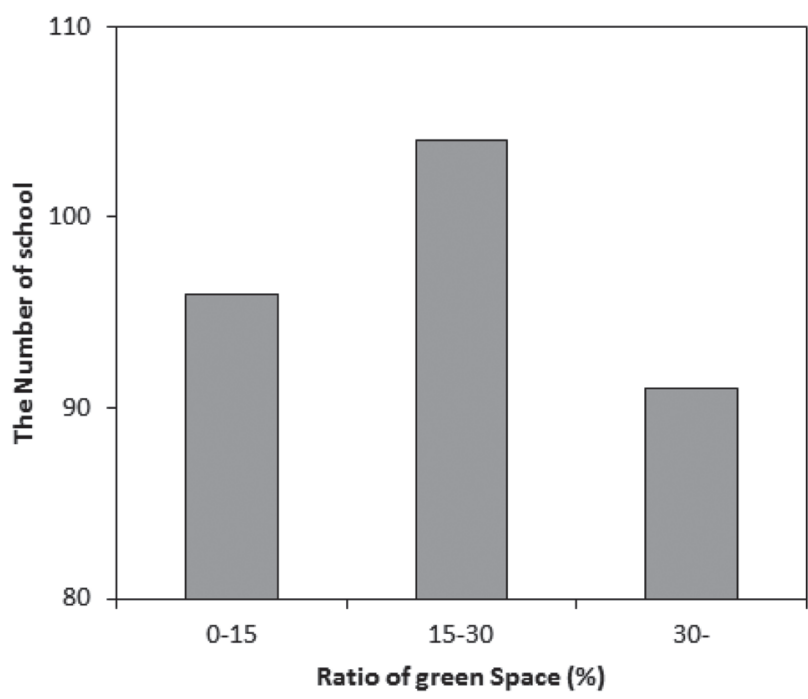

Fig. 3 Distribution of the green space ratio within $1 \mathrm{~km}$ radius circles around elementary schools.

Status of Green Space around Children in Malang

The average green space ratio within $1 \mathrm{~km}$ radius circles around each school was $26.7 \%\left(0.84 \mathrm{~km}^{2}\right)$. Although the governments of Indonesia (Ministry of Public Works, 2008) and the city of Nishinomiya (Susaki and Kubota, 2017) did not specify the optimal green space area for children in their regulations, we may be able to use their recommendations as guidelines for Malang. Thus, we categorized green space area into three grades based on $15 \%$ increments in the green space ratio within $1 \mathrm{~km}$ of each school (Fig. 3). The green space ratio was $<15 \%$ around 96 schools, and $15-30 \%$ around 104 schools. Our results suggest that nearly $70 \%$ of the elementary school children in Malang have little access to green space, even though experiences in nature during childhood are important for forming adult environmental opinions (Ewert et al., 2005; Jim and Shan, 2013). Because schools near the city center tended to have lower green space ratios (Fig. 4), children living near the city center may have less daily access to nature. 


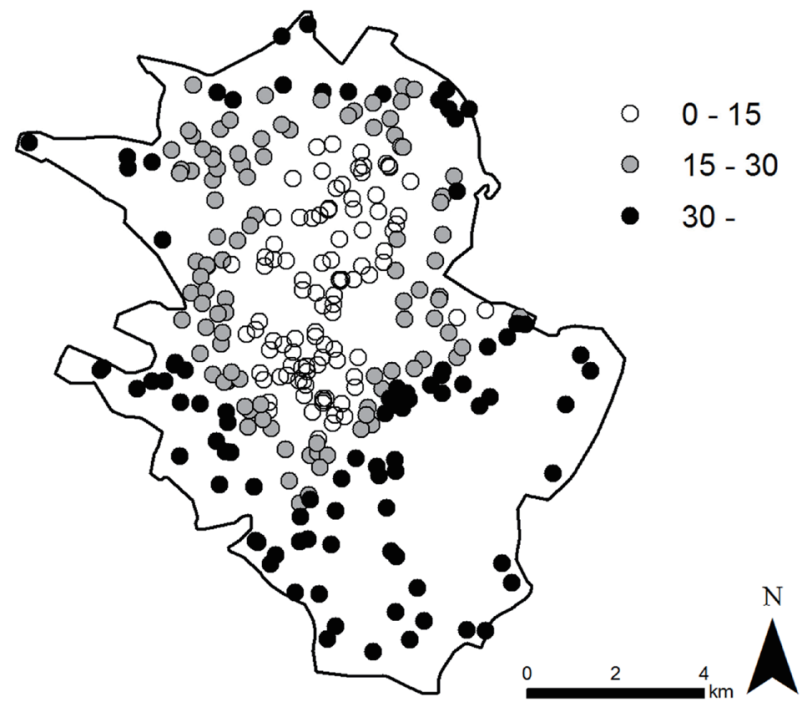

Fig. 4 Green space ratios (\%) within $1 \mathrm{~km}$ radius circles around each elementary school in Malang.

Recommendations for Improving the Green Space around Children in Malang

Green space is important for childhood development (Coolen and Meesters, 2012; Glackin and Jones, 2012; Ioja et al., 2014; Jansson et al., 2016; Kweon et al., 2017; Mizuki and Minami, 2003; Richardson et al., 2017; Seeland et al., 2009; Wu et al., 2014). Although elementary schools near the city center had less green space surrounding them, the green space ratio within $1 \mathrm{~km}$ of each school was more than $30 \%$ for schools located on the periphery of the city. Because Malang is highly urbanized, there is little open land left, and these green spaces should be conserved. To do this, the city's residents could lead conservation efforts (Sesanti et al., 2011) in cooperation with private companies. For example, some urban parks in Malang are maintained in partnership with private companies as part of their program of corporate social responsibility (Kurniawati et al., 2017). It is necessary to provide opportunities to stay in green spaces also should be considered. According to the 2016 Malang Regional Policy, 81 green spaces have been designated as urban parks, and 7 green spaces are described as urban forests (Malang City, 2016). These 88 parks and forests can complement the green space available on the periphery of the city to provide children with greater access to green space. The use of these green spaces should be more promoted. Form this point we might go on to an even more detailed examination of the usage of green spaces in our future research.

\section{ACKNOWLEDGEMENTS}

We would like to express my deepest gratitude to Prof. Ishikawa who provided carefully considered feedback and valuable comments. Special thanks also go to Mr. Kalther whose meticulous comments were an enormous help to us.

\section{LITERATURE CITED}

Achmad, A., Hasyim, S., Dahlan, B. and Aulia, D.N. (2015) Modelling of urban growth in tsunami-prone city using logistic regression: Analysis of Banda Aceh, Indonesia. Appl. Geogr. 62: 237-246

Agaton, M., Setiawan, Y. and Effendi, H. (2016) Land use/land cover change detection in an urban watershed: a case study of upper Citarum Watershed, West Java Province, Indonesia. Procedia Environ. Sci. 33: 654-660

Arifin, H.S. and Nakagoshi, N. (2011) Landscape ecology and urban biodiversity in tropical Indonesian cities. Landscape Ecol. Eng. 7: 33-43

Badan Pusat Statistik (2015) Statistics Malang City. https:// malangkota.bps.go.id/ (accessed 5 October 2018)

Byomkesh, T., Nakagoshi, N. and Dewan, A.M. (2012) Urbanization and green space dynamics in Greater Dhaka, Bangladesh. Landscape Ecol. Eng. 8: 45-58

Congalton, R.G. (1991) A review of assessing the accuracy of classifications of remotely sensed data. Remote Sens. Environ. 37: $35-46$

Coolen, H. and Meesters, J. (2012) Private and public green spaces: a meaningful but different setting. J. House and the Built Environ. 27: 49-67

Coombes, E., Jones, A.P. and Hillsdon, M. (2010) The relationship of physical activity and overweight to objectively measured green space accessibility and use. Soc. Sci. Med. 70: 816-822

Cox, D.T.C., Hudson, H.L., Shanahan, D.F., Fuller, R.A. and Gaston, K.J. (2017) The rarity of direct experiences of nature in an urban population. Landsc. Urban Plan. 160: 79-84

Dewan, A.M. and Yamaguchi, Y. (2009) Land use and land cover change in Greater Dhaka, Bangladesh: Using remote sensing to promote sustainable urbanization. Appl. Geogr. 29: 390 401

Elliott, S. and Chancellor, B. (2014). From forest preschool to bush kinder: An inspirational approach to preschool provision in Australia. Aust. J. Early Child. 39: 45-53

Ewert, A., Place, G. and Sibthorp, J. (2005) Early-Life outdoor experiences and an individual's environmental attitudes. Leis. Sci. 27: 225-239

Fjørtoft, I. and Sageie, J. (2000) The natural environment as a playground for children: Landscape description and analyses of a natural playscape. Landsc. Urban Plan. 48: 83-97

Forestry and Forest Products Research Institute (2012) REDDplus Cookbook. Forestry and Forest Products Research Institute. Tsukuba, $156 \mathrm{pp}$

Glackin, M. and Jones, B. (2012). Park and learn: improving opportunities for learning in local open spaces. Sch. Sci. Rev. 93: $105-113$

Ioja, C.I., Gradinaru, S.R., Onose, D.A., Vanau, G.O. and Tudor, A.C. (2014) The potential of school green areas to improve urban green connectivity and multifunctionality. Urban For. Urban Green. 13: 704-713 
Jansson, M., Elin, S. and Wales, M. (2016) The role of green spaces and their management in a child-friendly urban village. Urban For. Urban Green. 18: 228-236

Jim, C.Y. and Shan, X. (2013) Socioeconomic effect on perception of urban green spaces in Guangzhou, China. Cities 31: 123-131

Kirmanto, D., Ernawi, I.S. and Djakapermana, R.D. (2012) Indonesia green city development program: an Urban Reform. Ministry of Public Works, Indonesia. 48th ISOCARP Congress 2012

Kurniawati, D.E., Kusumaningrum, D.N. and Haffsari, P.P. (2017) Revitalization of green open space (GOS) in Kota Malang as the government response to urban social sustainability. Journal of Social Science and Humanities Research 2: $1-11$

Kusimi, J.M. (2008) Assessing land use and land cover change in the Wassa West District of Ghana using remote sensing. GeoJournal 71: 249-259

Kweon, D.K., Ellis, C.D., Lee, J. and Jacobs, K. (2017) The link between school environments and student academic performance. Urban For. Urban Green. 23: 35-43

Maas, J., Verheij, R.A., Groenewegen, P.P., de Vries, S. and Spreeuwenberg, P. (2006) Green space, urbanity, and health: how strong is the relation? J. Epidemiol. Community Health 60: $587-592$

MacEachren, Z. (2013) The Canadian forest school movement. Learn. Landsc. 7: 219-233.

Malang City (2016) Keputusan Walikota Malang No. 188.45/184/35.73.112/2016 Tahun 2016 [Decree of Malang City's Mayor No.188.45/184/35.73.112/2016 Year 2016]. http://disperkim.malangkota.go.id/component/upload/document/taman_kota/TKDOC_171205155438.pdf (accessed 25 December 2018) (in Indonesian)

Malang District Board of Education (2018) Data Sekolah Tingkat SD/SDLB/MI [School data for elementary grades]. https://diknas.malangkota.go.id/?page_id=2964 (accessed 25 December 2018) (in Indonesian)

McDonald, N.C. (2008) Children's mode choice for the school trip: the role of distance and school location in walking to school. Transportation 35: 23-35

Ministry of Public Works (2008) Peraturan Menteri Pekerjaan Umum No. 05/PRT/M/2008 tentang Pedoman Penyediaan dan Pemanfaatan Ruang Terbuka Hijau di Kawasan Perkotaan [Minister of Public Works regulation No. 05/PRT/M/2008 concerning guidelines for the provision and use of green open space in urban areas]. (in Indonesian)

Mizuki, S. and Minami, H. (2003) Relation of children's behavior and street environments when returning home from school. J. Archit. Plann. 574: 61-68 (in Japanese with English abstract) OECD (2013) Frameworks and sector policies for urban development in Chile OECD Urban Policy Reviews, Chile 2013

Pemerintah Kota Malang (2018) Geografis [Geography]. https:// malangkota.go.id/ (accessed 5 October 2018)
Purwanto, Utomo, D.H., and Kurniawan, B.R. (2016) Spatio temporal analysis trend of land use and land cover change against temperature based on remote sensing data in Malang City. Procedia Soc. Behav. Sci. 227: 232-238

Ramdani, F., Putra, A.F. and Utomo, B.N. (2015) Historical land use transformation in virtual geo-library. ISPRS Int. J. Geo-Inf 4: 1500-1511

Richardson, E.A., Pearce, J., Shortt, N.K. and Mitchell, R. (2017) The role of public and private natural space in children's social, emotional and behavioural development in Scotland: A longitudinal study. Environ. Res. 158: 729-736

Roy, S., Byrne, J. and Pickering, C. (2012) A systematic quantitative review of urbantree benefits, costs, and assessment methods across cities in different climaticzones. Urban For. Urban Green. 4: 351-363

Schäffer, S.D., and Kistemann, T. (2012) German forest kindergartens: Healthy childcare under the leafy canopy. Child. Youth Environ. 22: 270-279

Seeland, K., Dübendorfer, S. and Hansmann, R. (2009) Forest policy and economics making friends in Zurich's urban forests and parks: The role of public green space for social inclusion of youths from different cultures. For. Policy Econ. 11:10-17

Sesanti, N., Kurniawan, E.B. and Anggaraeni, M. (2011) Optimasi Hutan Sebagai Penghasil Oksigen Kota Malang [Forest optimization as oxygen producer of Malang City]. Jurnal Tata Kota dan Daerah 3: 65-73 (in Indonesian with English abstract)

Story, M. and Congalton, R.G. (1983) Accuracy assessment: A user's perspective. Photogramm. Eng. Remote Sensing 52: 397-399

Susaki, J. and Kubota, S. (2017) Automatic assessment of green space ratio in urban areas from mobile scanning data. Remote Sens. 9: 215. doi:10.3390/rs9030215

United Nations (2014) World urbanization prospects. http://esa. un.org/unpd/wup/ (accessed 20 May 2016)

Wolch, J.R., Byrne, J. and Newell, J.P. (2014) Urban green space, public health, and environmental justice: The challenge of making cities 'just green enough'. Landsc. Urban Plan. 125: 234-244

Wolfersberger, J., Delacote, P. and Garcia, S. (2015) An empirical analysis of forest transition and land-use change in developing countries. Ecol. Econ. 119: 241-251

World Bank (2016) Urban Population. http://data.worldbank. org/ (accessed 5 October 2018)

Wu, D.D., McNeely, E., Cedeño-Laurent, J.G., Pan, W.C., Adamkiewicz, G., Dominici, F., Lung, S.C., Su, H.J. and Spengler, J.D. (2014) Linking student performance in Massachusetts elementary schools with the "Greenness" of school surroundings using remote sensing. PLoS ONE 9: e108548. doi:10.1371/journal.pone. 0108548

(Received 24 August 2018)

(Accepted 24 January 2019)

(J-STAGE Advance Published 29 March 2019) 